Prepared in cooperation with the Bureau of Reclamation

\title{
Hydrologic Data for the Walker River Basin, Nevada and California, Water Years 2010-14
}

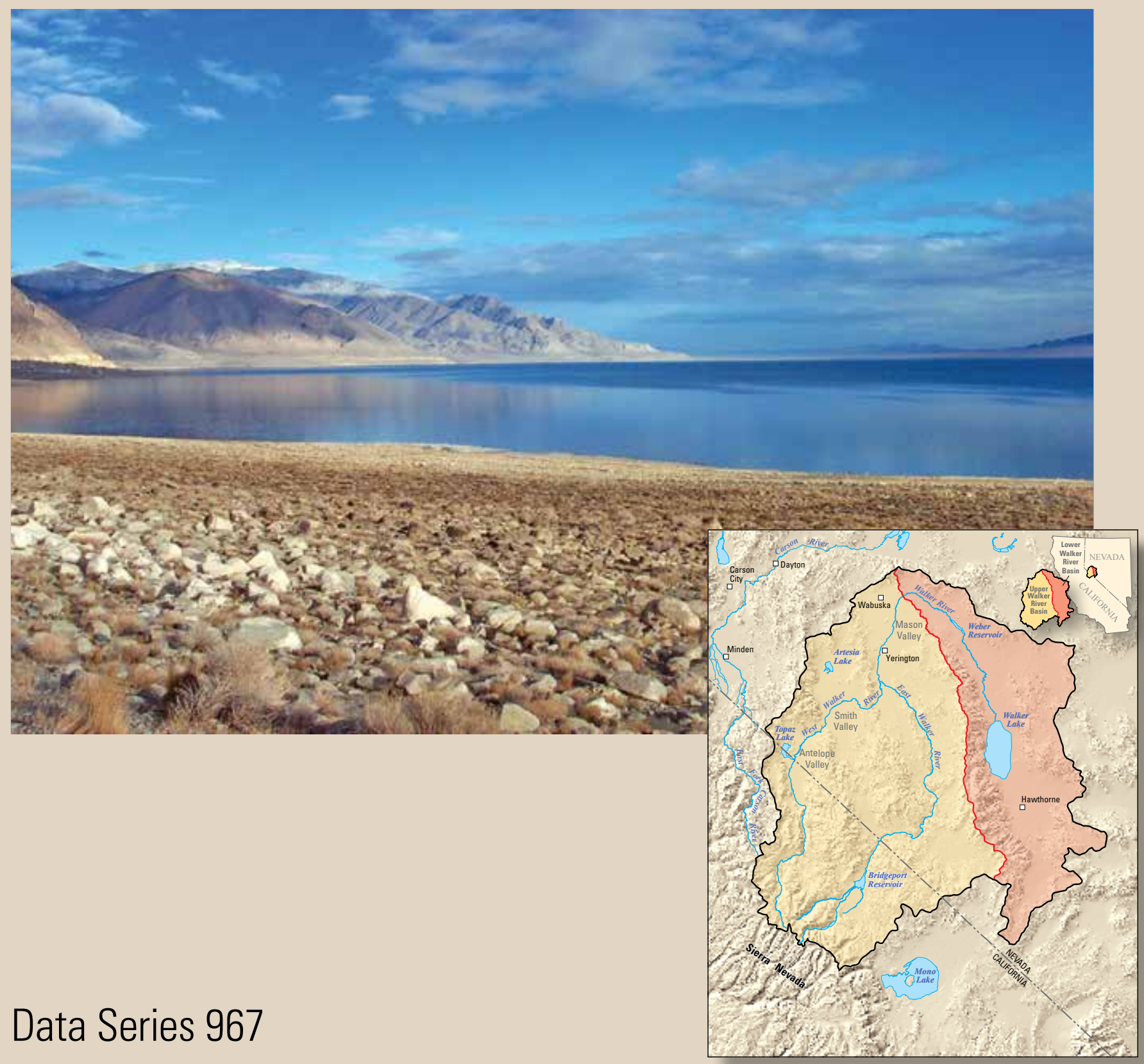

U.S. Department of the Interior

U.S. Geological Survey 



\section{Hydrologic Data for the Walker River Basin, Nevada and California, Water Years 2010-14}

By Michael T. Pavelko and Erin L. Orozco

Prepared in cooperation with the Bureau of Reclamation

Data Series 967

U.S. Department of the Interior

U.S. Geological Survey 


\title{
U.S. Department of the Interior SALLY JEWELL, Secretary
}

\section{U.S. Geological Survey \\ Suzette M. Kimball, Acting Director}

\author{
U.S. Geological Survey, Reston, Virginia: 2015
}

For more information on the USGS - the Federal source for science about the Earth, its natural and living resources, natural hazards, and the environment—visit http://www.usgs.gov or call 1-888-ASK-USGS.

For an overview of USGS information products, including maps, imagery, and publications, visit http://www.usgs.gov/pubprod/.

Any use of trade, firm, or product names is for descriptive purposes only and does not imply endorsement by the U.S. Government.

Although this information product, for the most part, is in the public domain, it also may contain copyrighted materials as noted in the text. Permission to reproduce copyrighted items must be secured from the copyright owner.

Suggested citation:

Pavelko, Michael T., and Orozco, Erin L., 2015, Hydrologic data for the Walker River Basin, Nevada and California, water years 2010-14: U.S. Geological Survey Data Series 967, 17 p., plus appendixes, http://dx.doi.org/10.3133/ ds967.

ISSN 2327-638 (online) 


\section{Contents}

Abstract
Introduction
$\quad$ Purpose and Scope
Data-Collection Methods
Hydrologic Data
Summary
References Cited
Appendixes

\section{Figures}

1. Map showing data-collection sites for the Walker River Basin study, water years

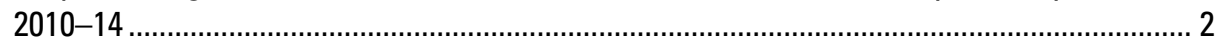

\section{Tables}

1. Data-collection sites for the Walker River Basin study, water years 2010-14 ................ 5

2. Water-chemistry analytes for the Walker River Basin study, water years 2010-14 .......13 


\section{Conversion Factors, Datums, and Water-Quality Units}

International System of Units to Inch/Pound

\begin{tabular}{lccc}
\hline & Multiply & By & To obtain \\
\hline & Length & & \\
\hline meter $(\mathrm{m})$ & 0.3048 & foot $(\mathrm{ft})$ & \\
\hline
\end{tabular}

Temperature in degrees Celsius $\left({ }^{\circ} \mathrm{C}\right)$ can be converted to degrees Fahrenheit ( $\left.{ }^{\circ} \mathrm{F}\right)$ as follows:

${ }^{\circ} \mathrm{F}=\left(1.8 \times{ }^{\circ} \mathrm{C}\right)+32$

Temperature in degrees Fahrenheit $\left({ }^{\circ} \mathrm{F}\right)$ can be converted to degrees Celsius $\left({ }^{\circ} \mathrm{C}\right)$ as follows:

${ }^{\circ} \mathrm{C}=\left({ }^{\circ} \mathrm{F}-32\right) / 1.8$

Concentrations of chemical constituents in water are given either in milligrams per liter (mg/L) or micrograms per liter $(\mu \mathrm{g} / \mathrm{L})$.

Specific conductance is given in microsiemens per centimeter at 25 degrees Celsius $(\mu \mathrm{S} / \mathrm{cm}$ at $\left.25^{\circ} \mathrm{C}\right)$.

Vertical coordinate information is referenced to the North American Vertical Datum of 1988 (NAVD 88).

Horizontal coordinate information is referenced to the North American Datum of 1983 (NAD 83).

Altitude, as used in this report, refers to distance above the vertical datum.

\section{Abbreviations}

USGS U.S. Geological Survey

NWIS National Water Information System

NWISWeb National Water Information System web portal 


\title{
Hydrologic Data for the Walker River Basin, Nevada and California, Water Years 2010-14
}

\author{
By Michael T. Pavelko and Erin L. Orozco
}

\section{Abstract}

Walker Lake is a threatened and federally protected desert terminal lake in western Nevada. To help protect the desert terminal lake and the surrounding watershed, the Bureau of Reclamation and U.S. Geological Survey have been studying the hydrology of the Walker River Basin in Nevada and California since 2004. Hydrologic data collected for this study during water years 2010 through 2014 included groundwater levels, surface-water discharge, water chemistry, and meteorological data. Groundwater levels were measured in wells, and surface-water discharge was measured in streams, canals, and ditches. Water samples for chemical analyses were collected from wells, streams, springs, and Walker Lake. Chemical analyses included determining physical properties; the concentrations of major ions, nutrients, trace metals, dissolved gases, and radionuclides; and ratios of the stable isotopes of hydrogen and oxygen. Walker Lake water properties and meteorological parameters were monitored from a floating platform on the lake. Data collection methods followed established U.S. Geological Survey guidelines, and all data are stored in the National Water Information System database. All of the data are presented in this report and accessible on the internet, except multiple-depth Walker Lake water-chemistry data, which are available only in this report.

\section{Introduction}

The Walker River Basin is a hydrologically closed surfacewater drainage basin encompassing about 3,950 square miles in Nevada and California (fig. 1). Much of the surface-water flow in the basin is used for irrigation and originates as snowmelt in the adjacent Sierra Nevada. Surface water not used for irrigation flows through several valleys, joins the Walker River, and then discharges into Walker Lake (fig. 1). Walker Lake is a desert terminal lake that is a remnant of Lake Lahontan, which extended over much of western Nevada during the Pleistocene (Reheis, 1999). As a terminal lake, there is no surface-water discharge. Evaporation and evapotranspiration (ET) account for about 99 percent of Walker Lake discharge; diverted local runoff and pumping, combined, account for about 1 percent of lake discharge (Lopes and Allander, 2009a).
The water level and chemistry of Walker Lake are sensitive to inflow from the Walker River. The lake level has been declining since the late 1800 s, when diversions for irrigation began (Dilts and others, 2012). Based on 2015 lake levels at the U.S. Geological Survey (USGS) Walker Lake, near Hawthorne, Nevada, monitoring station (fig. 1), the lake level has declined more than 160 feet since the diversions began, which is equivalent to a loss of about 7,850,000 acre-feet of stored water (Lopes and Smith, 2007). Because evaporation accounts for the vast majority of discharge from the lake, most dissolved solids that enter the lake remain in the lake. Evaporation has increased the concentrations of dissolved solids in the lake and has affected the lake ecosystem, including the disappearance of the Lahontan Cutthroat trout (Oncorhynchus clarkii henshawi), which is listed as a threatened species under the Endangered Species Act (Allander and others, 2009).

In response to the 2002 Farm Bill (Section 2507 of Public Law 107-171 and Section 207 of Public Law 108-7), the Bureau of Reclamation and the USGS began the Walker River Basin study in 2004. The primary goals of the laws are to provide water to at-risk natural desert terminal lakes, including Walker Lake, and to restore the fish, wildlife, and associated habitats of the lake's watersheds. To help accomplish the Walker River Basin study goals, the USGS has been tasked with (1) quantifying the volume of streamflow in the Walker River Basin and determining how much of the flow is from each valley, (2) determining ET losses from vegetation and evaporation from the lake surface, (3) developing an improved water budget for Walker Lake, and (4) determining how water-use changes in the Walker River Basin will affect streamflows to Walker Lake (U.S. Geological Survey, 2005). For this study, the Walker River Basin is divided into an upper and lower basin, relative to the USGS Walker River, near Wabuska, Nevada, streamgaging station (fig. 1). Hydrologic data collected by the USGS were focused on the lower basin from water years 2004 through 2009, and data collected for the present study are focused on the upper basin from water years 2010 through 2014 . 


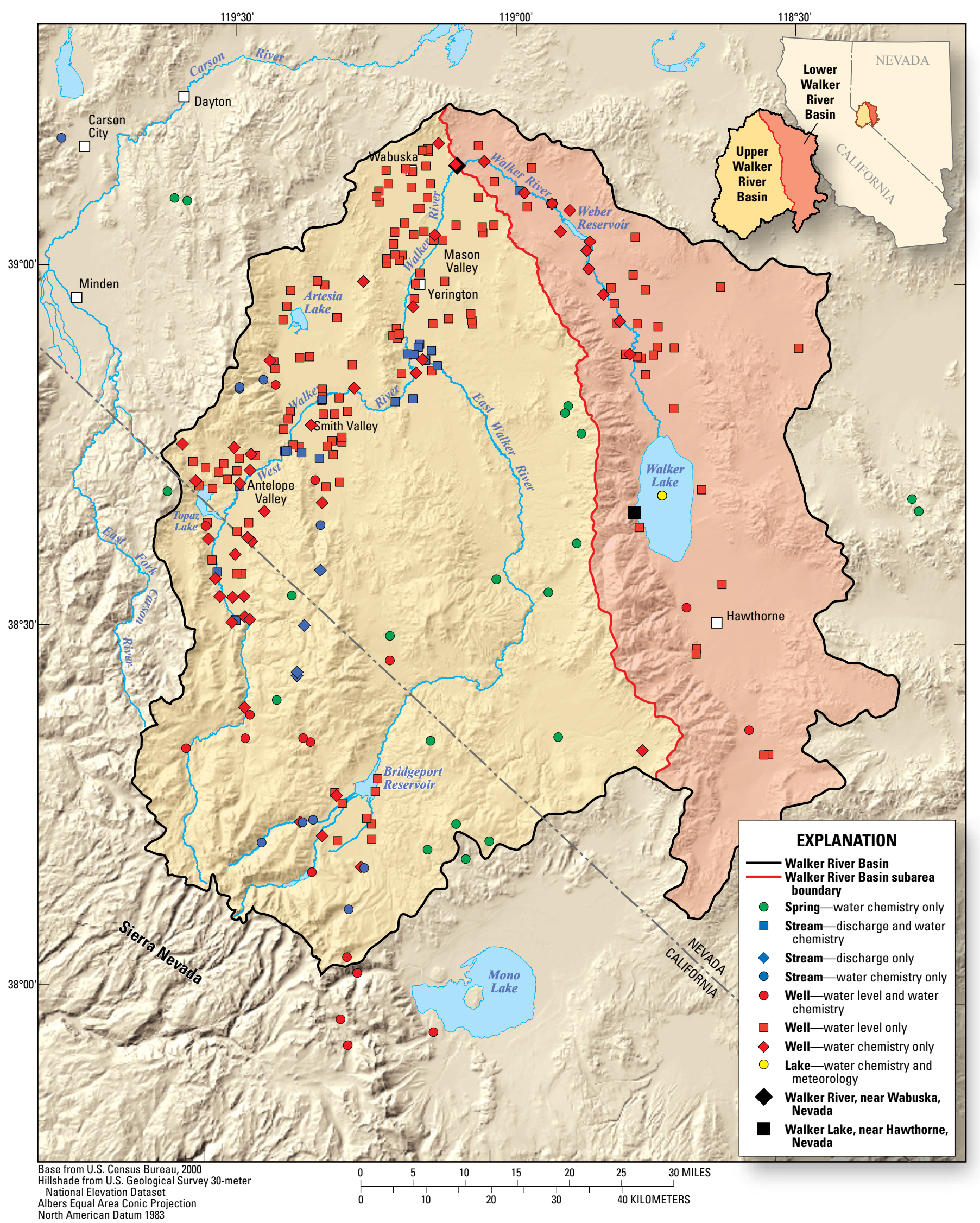

Figure 1. Data-collection sites for the Walker River Basin study, water years 2010-14. 
Hydrologic data collected by the USGS for the Walker River Basin study are stored in the USGS National Water Information System (NWIS) database and are documented in several USGS interpretive reports. Lopes and Smith (2007) describes the bathymetry of Walker Lake. Allander and others (2009) quantifies ET from the lower Walker River Basin for water years 2005-07, including evaporation from Walker Lake. Lopes and Allander (2009a) describes the hydrologic setting and conceptual hydrologic model of the Walker River Basin, and Lopes and Allander (2009b) describes the water budget of the lower Walker River Basin and Walker Lake. Allander and others (2014) documents numerical hydrologic models, and surface-water and groundwater simulations of the lower Walker River Basin.

\section{Purpose and Scope}

The purpose of this report is to document hydrologic data and data-collection methods for the Walker River Basin study for water years 2010-14 (October 1, 2009-September 30, 2014). During that time, data were collected for 212 wells, 34 surface-water sites, 20 springs, and 12 sites on Walker Lake (table 1 and fig. 1). Four wells, one stream, and six springs outside of the Walker River Basin (table 1 and fig. 1) were monitored to gain information from adjacent basins and to determine if trends in the Walker River Basin occur outside the study area boundary. Hydrologic data collected during water years 2010-14 included groundwater levels, surfacewater discharge, water chemistry, and meteorological data. Water-chemistry data included physical properties; concentrations of major ions, nutrients, trace metals, dissolved gases, and radionuclides; and ratios of the stable isotopes of hydrogen and oxygen. Meteorological data included air temperature, barometric pressure, wind speed, relative humidity, and solar radiation. Walker Lake water-chemistry data and meteorological data were collected from a floating platform near the center of the lake. Walker Lake water-chemistry data include data from near the lake surface and from multiple depths below the surface. All of the data are presented in this report and accessible from the NWIS web portal (NWISWeb; U.S. Geological Survey, 2015), except multiple-depth Walker Lake waterchemistry data, which are available only in this report.

\section{Data-Collection Methods}

Data-collection methods for the Walker River Basin study followed established USGS guidelines, and all hydrologic data are stored in the NWIS database. Groundwater levels in wells were measured with electronic or steel tapes (Cunningham and Schalk, 2011). Periodic surface-water discharge in streams and irrigation canals and ditches was measured with a FlowTracker acoustic Doppler velocimeter (Turnipseed and Sauer, 2010). Water-chemistry samples from wells, streams, springs, and near the surface of Walker Lake were collected following standard USGS protocols (U.S. Geological Survey, variously dated), and water-chemistry data from multiple depths of Walker Lake were obtained following methods established from previous USGS studies (Rowland and others, 2006; Wagner and others, 2006; Veley and Moran, 2012).

Water temperature, $\mathrm{pH}$, specific conductance, dissolved oxygen, and turbidity were measured with a calibrated multisensor water-chemistry sonde in a flow-through chamber. Alkalinity and concentrations of carbonate and bicarbonate were determined in the field by using the inflection point, incremental titration method (U.S. Geological Survey, variously dated). Concentrations of dissolved solids, major ions, nutrients, trace metals, and radionuclides were determined at the USGS National Water Quality Laboratory (NWQL); concentrations of dissolved gases were determined at the USGS Reston Groundwater Dating Laboratory; and ratios of the stable isotopes of hydrogen and oxygen were determined at the USGS Reston Stable Isotope Laboratory (table 2).

Groundwater samples were collected from wells with a pump and filtration system. Most wells were sampled with dedicated submersible pumps, and wells without dedicated pumps were sampled with a Bennett pump. Groundwater samples for laboratory analyses were collected only after water temperature, $\mathrm{pH}$, specific conductance, and dissolved oxygen values were considered stable (U.S. Geological Survey, variously dated). Stream-water samples were collected by dipping a bottle along the stream bank where the water was well mixed. Stream-water samples were collected from five continuous streamgaging sites about every 2 weeks and from nine periodically measured streams once or twice during the study. Spring-water samples were collected by dipping a bottle into the spring as near to the orifice as possible.

Walker Lake water-chemistry data are from a floating platform near the center of the lake (fig. 1). Near-surface samples were collected by dipping a bottle just below the lake surface. Water chemistry at multiple depths was monitored with an automated variable-depth profiling system. The profiling system, equipped with a winch and a sonde, collected data at depths of $1,3,5,7,9,11,13,15,17$, and 19 meters (m) below the lake surface every 4 hours. During site visits, sonde sensors were cleaned and calibrated, and the water depth was measured to verify that the lake was deeper than $19 \mathrm{~m}$. 
Meteorological data were recorded hourly with sensors installed on the Walker Lake floating platform. Air temperature and relative humidity were measured $2.2 \mathrm{~m}$ above the lake surface, wind speed was measured $2.9 \mathrm{~m}$ above the lake surface, barometric pressure was measured $1.3 \mathrm{~m}$ above the lake surface, and solar radiation was measured $2.8 \mathrm{~m}$ above the lake surface. The meteorological sensors were factory calibrated before and after data collection to determine and ensure accuracy. In the field, routine visual inspections and maintenance ensured the sensors were clean and free of debris. When necessary, sensors were cleaned with a cotton swab and deionized water.

\section{Hydrologic Data}

Groundwater levels were measured in 195 wells, totaling 2,070 measurements, from October 2, 2009, to March 18, 2014 (appendix 1). Surface-water discharge was measured in 11 streams, 9 irrigation ditches, and 4 irrigation canals, totaling 104 measurements, from January 6, 2011, to October 29, 2012 (appendix 2).

Groundwater-chemistry samples were collected from 70 wells, totaling 107 samples, from September 15, 2010, to September 21, 2012 (appendix 3). The samples were analyzed for water temperature, $\mathrm{pH}$, specific conductance, dissolved oxygen, alkalinity, bicarbonate, and carbonate; concentrations of dissolved solids, major ions, nutrients, trace metals, radionuclides, and dissolved gases; and ratios of the stable isotopes of hydrogen and oxygen (table 2).
Stream water-chemistry samples were collected from 14 streams, totaling 359 samples, from October 21, 2010, to September 27, 2013 (appendix 4). The samples were analyzed for water temperature, $\mathrm{pH}$, specific conductance, concentrations of chloride and bromide, and ratios of the stable isotopes of hydrogen and oxygen. Bromide analyses were discontinued after analyzing 25 samples from four streams because bromide concentrations were below detectable levels.

Spring water-chemistry samples were collected from 20 springs, totaling 20 samples, from August 18, 2011, to August 15, 2012 (appendix 5). The samples were analyzed for water temperature, $\mathrm{pH}$, specific conductance, chloride concentration, and ratios of the stable isotopes of hydrogen and oxygen.

Walker Lake water-chemistry samples from near the lake surface were collected on November 2, 2010, and January 14, 2014 (appendix 6). The near-surface samples were analyzed for water temperature, $\mathrm{pH}$, specific conductance, and dissolved-solids concentration. Walker Lake water-chemistry data from $1,3,5,7,9,11,13,15,17$, and $19 \mathrm{~m}$ below the lake surface were collected near continuously from May 3, 2011, to June 9, 2013 (appendix 6). Data collected at multiple depths were water temperature, $\mathrm{pH}$, specific conductance, dissolved oxygen, turbidity, and water depth.

Meteorological data were collected on the Walker Lake floating platform from March 30, 2011, to September 30, 2013, (appendix 6) and included air temperature, barometric pressure, wind speed, relative humidity, and solar radiation. 
Hydrologic Data 5

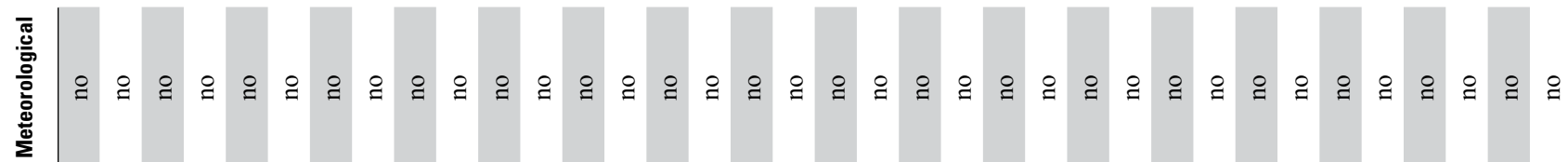

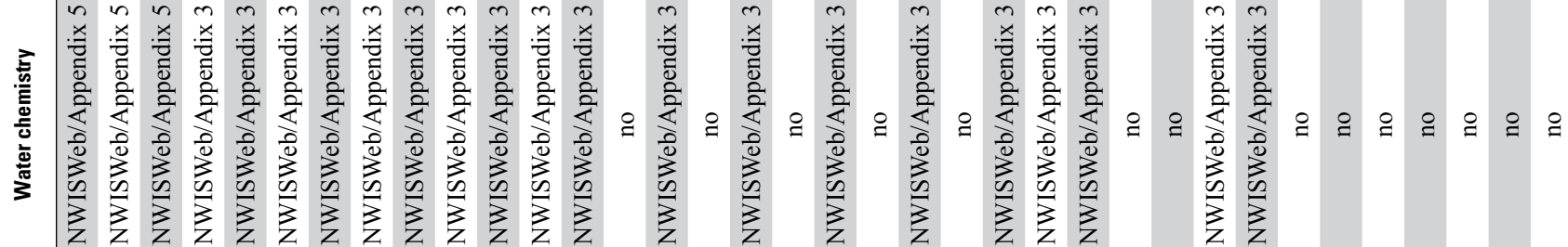

兽 离

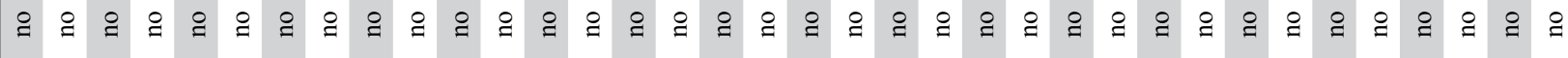

$\ddot{ \pm}$

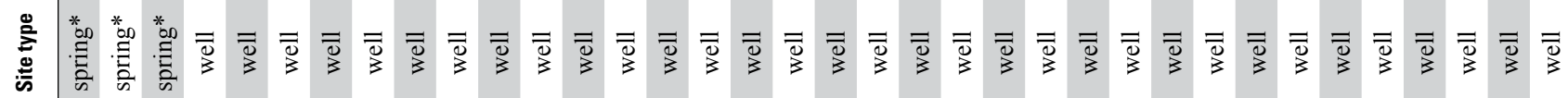

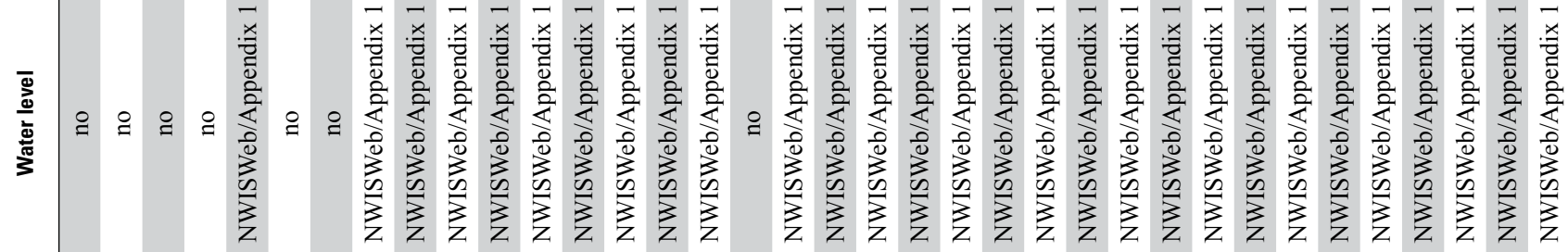

$$
\text { 들 }
$$

峁

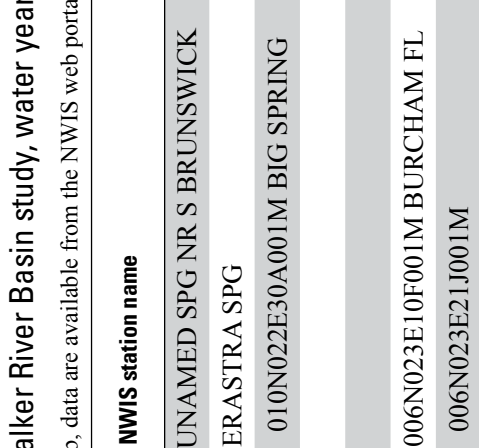

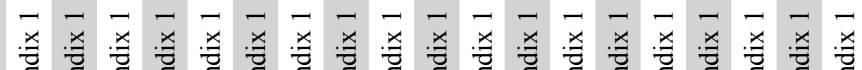

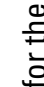

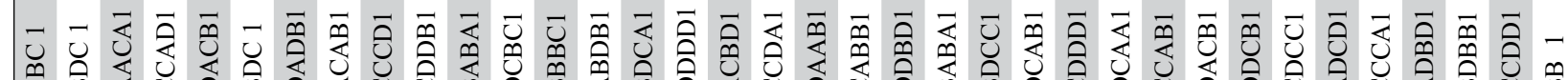
ț $\stackrel{s}{\omega}$

.

을

ง

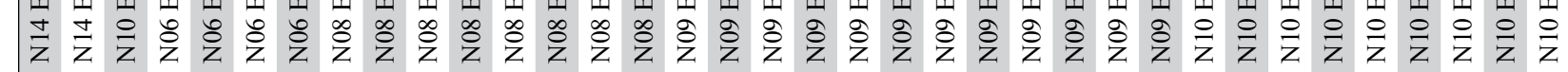

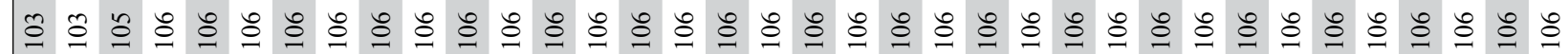

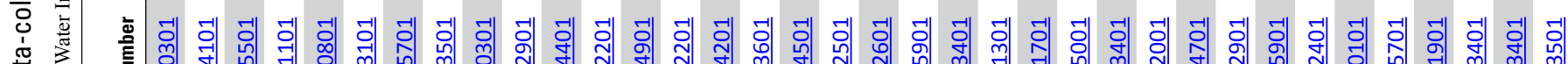

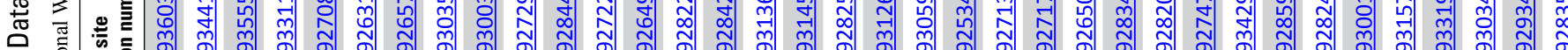

- 蒙 


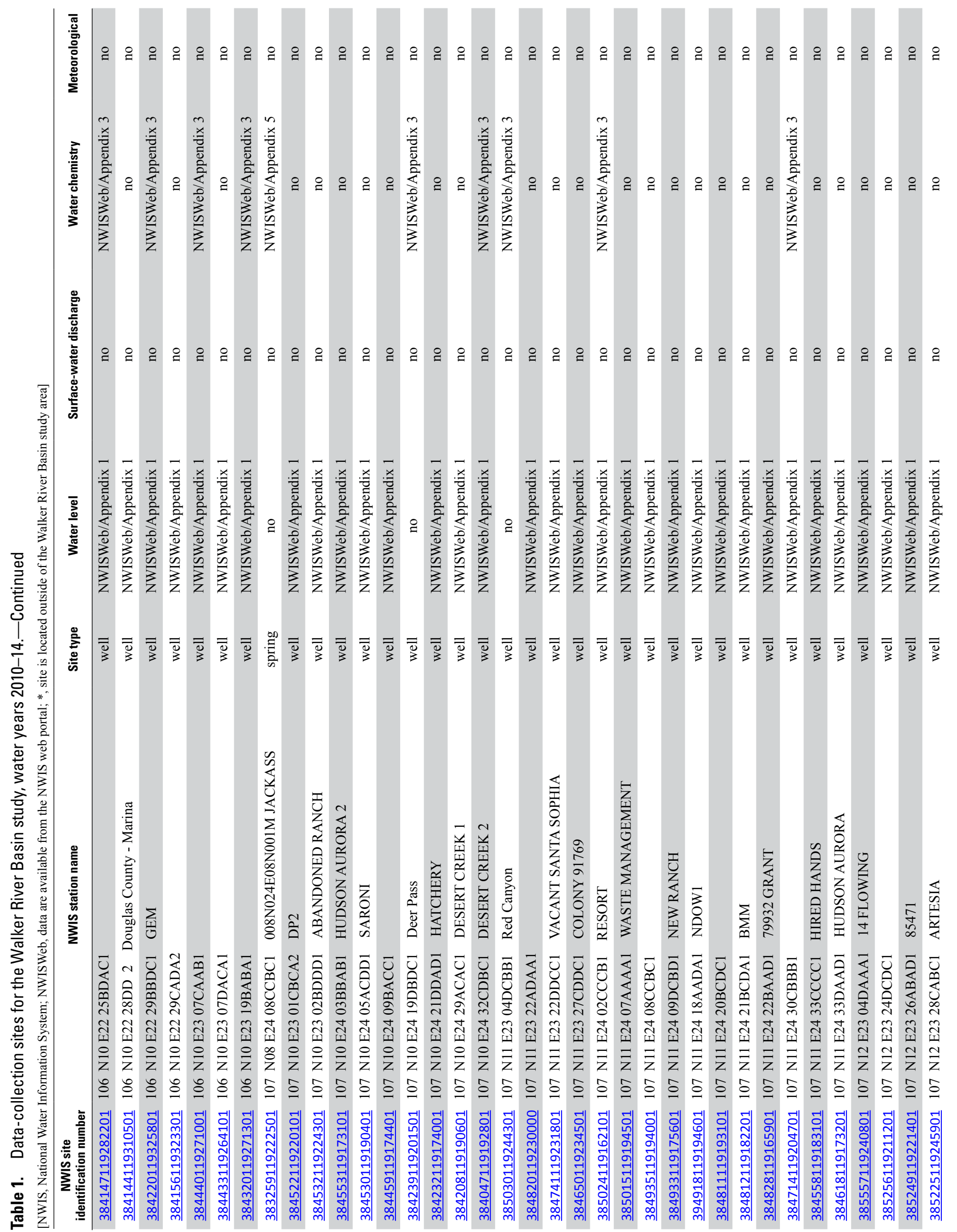


Hydrologic Data 7

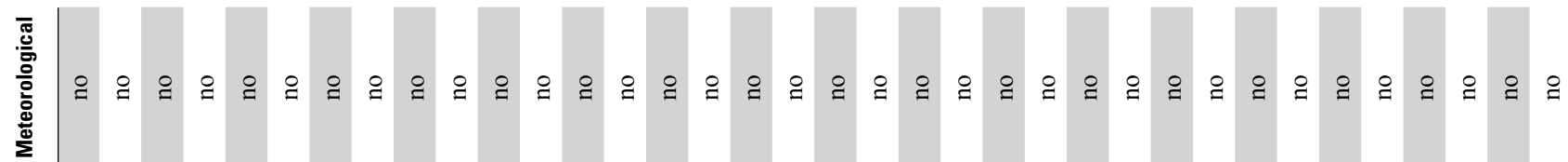

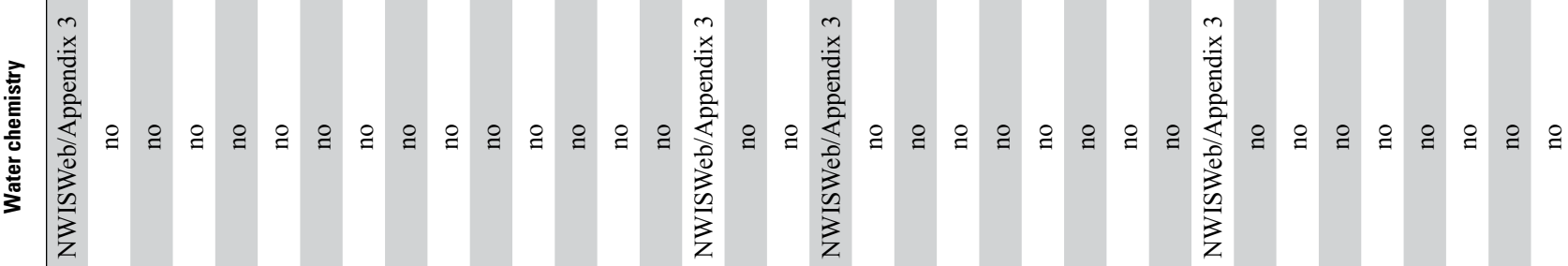

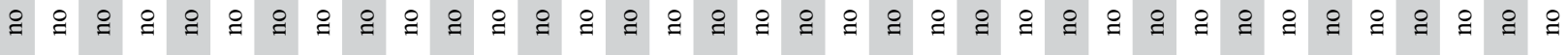

递

兽

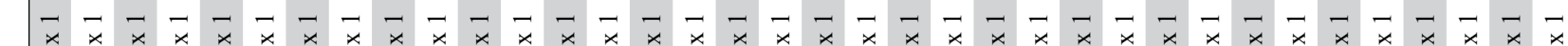

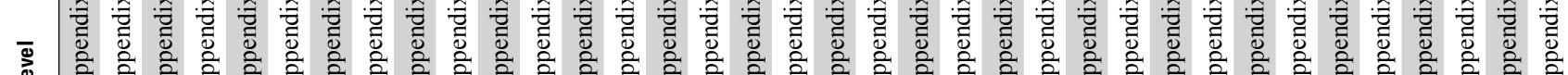

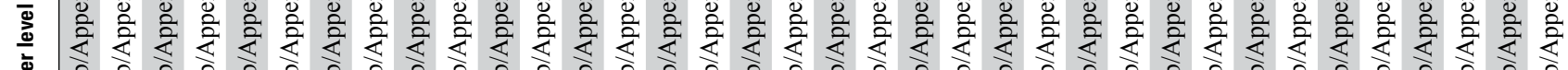
范

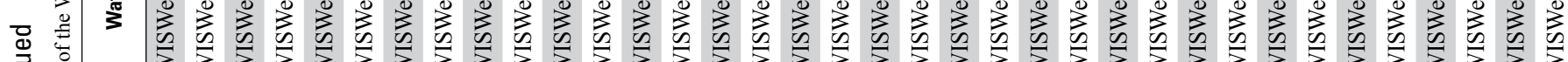

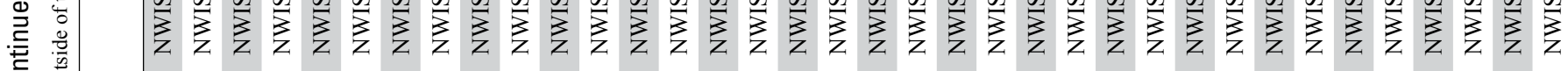

نे

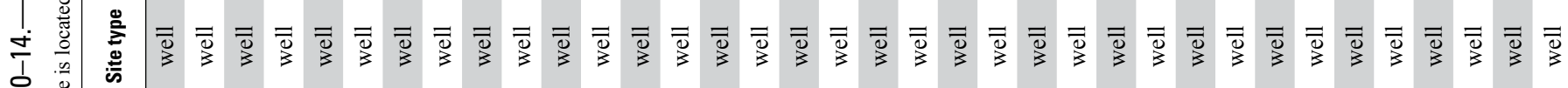

들

$\stackrel{\infty}{\stackrel{\infty}{\varpi}}$

离

言

突

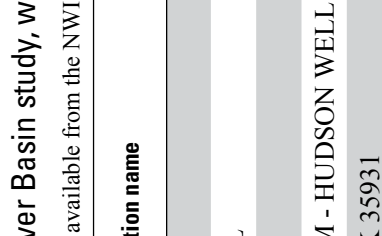

$\stackrel{\sim}{2}$

㐫

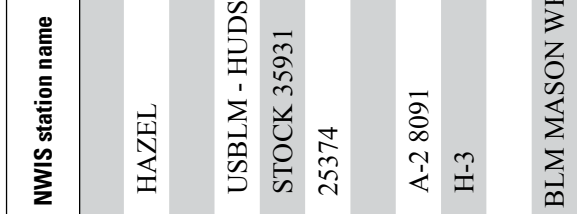

यक तै

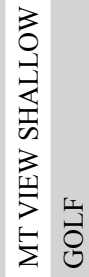

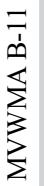

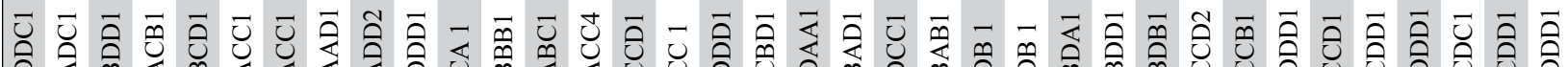

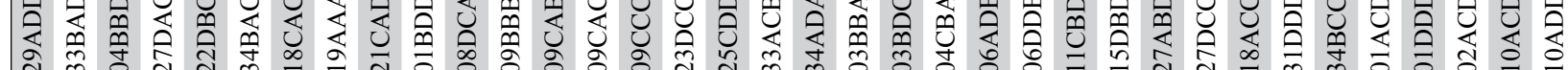

密

$\Phi$

兽

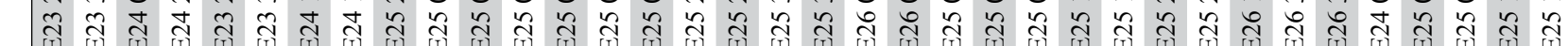

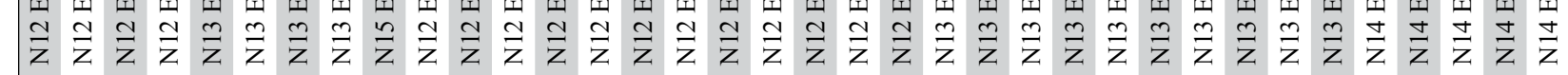

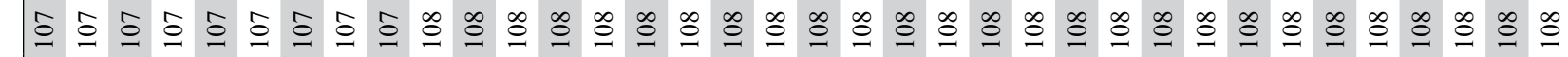

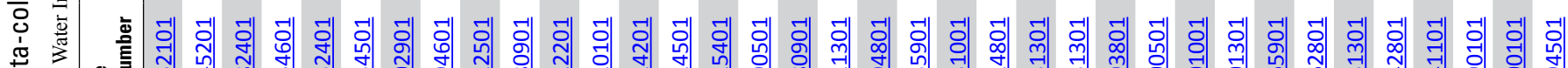

ॠ

$\therefore$ -

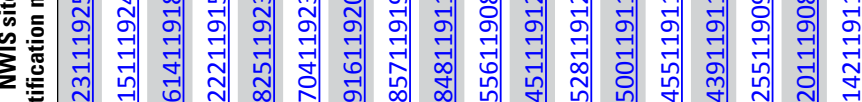

$\frac{0}{\frac{0}{a}}$ 


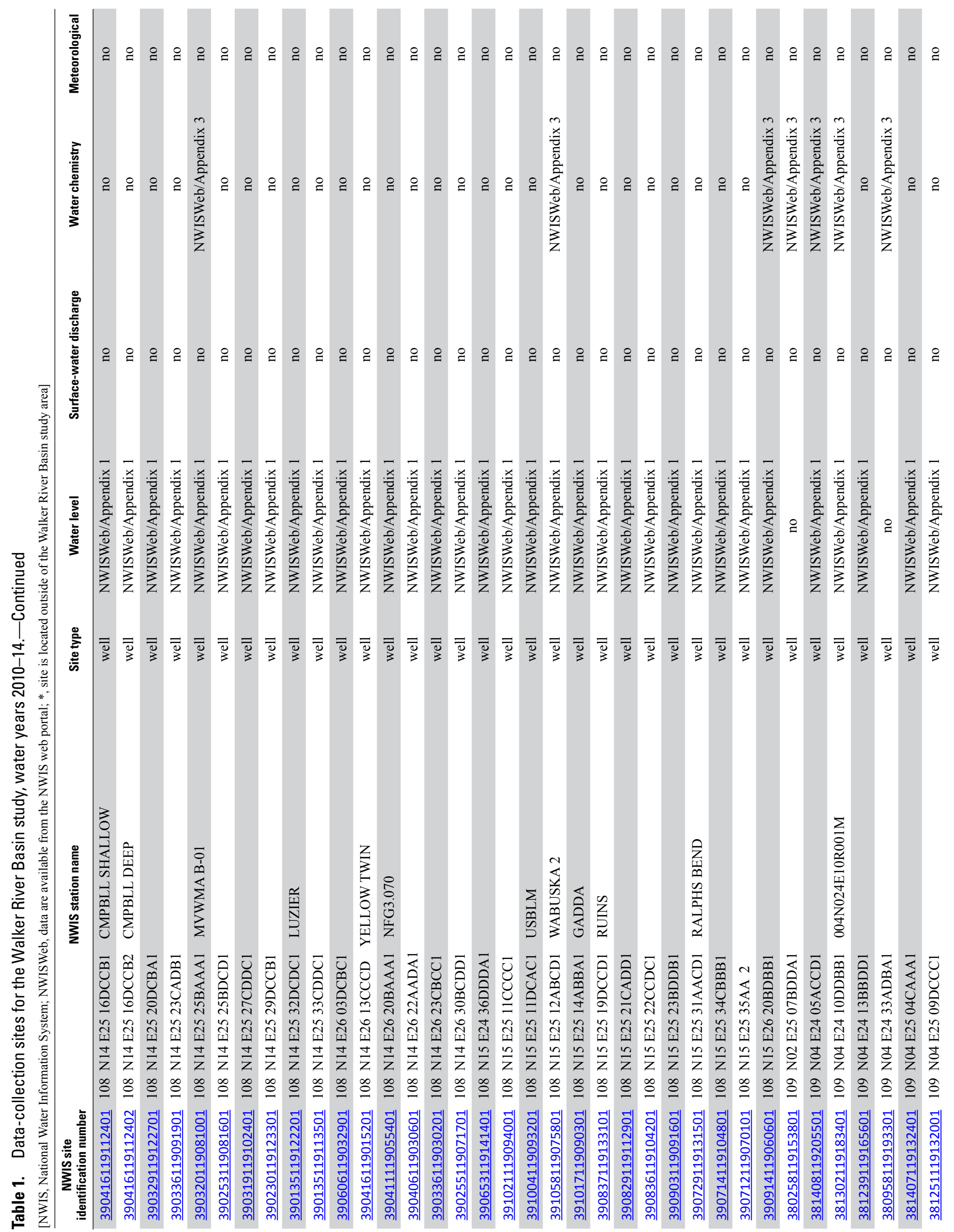




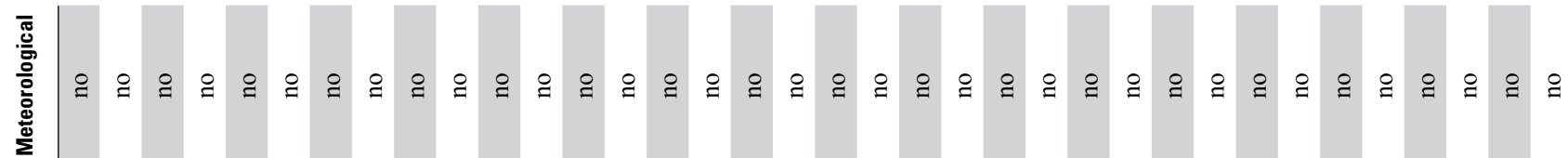

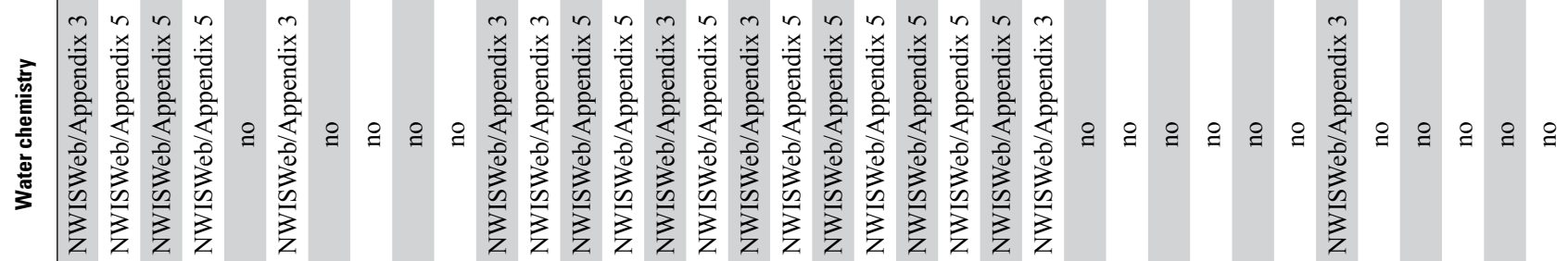

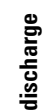

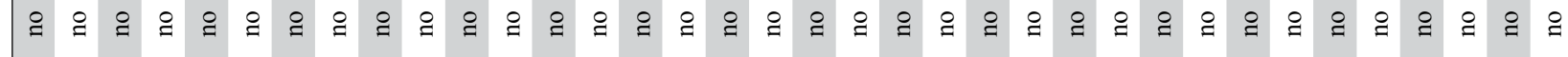

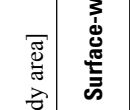

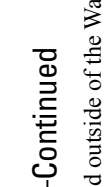

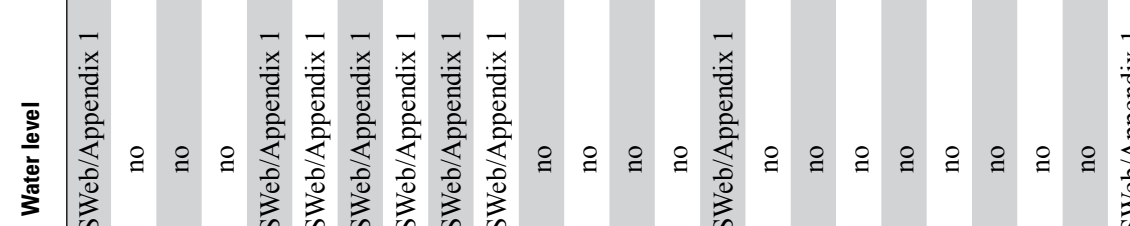

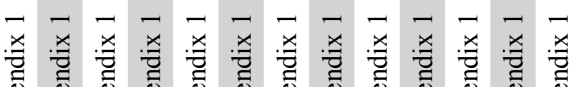

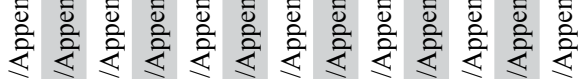
के के के के के के के के के के के के के

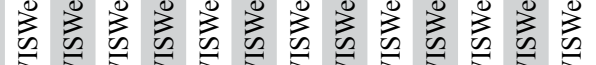

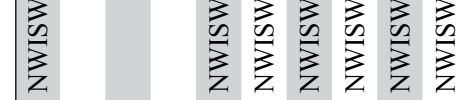
$\sum_{z}^{\infty}$

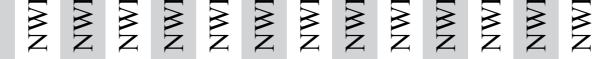

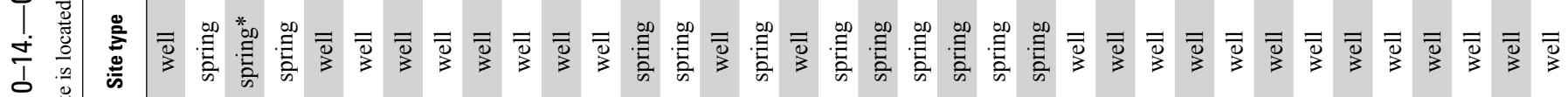

$$
\text { 도ำ }
$$

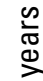

$\sum_{\substack{\Phi \\ \Phi}}^{\infty}$

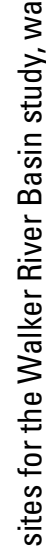

竞

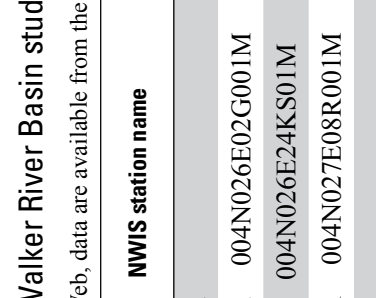

.

兽

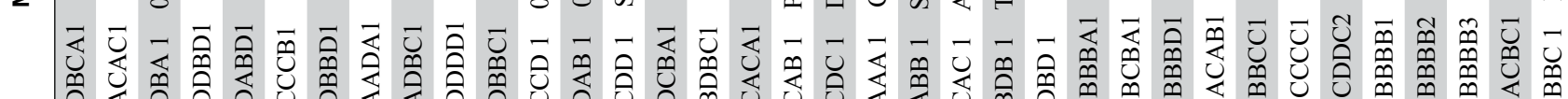

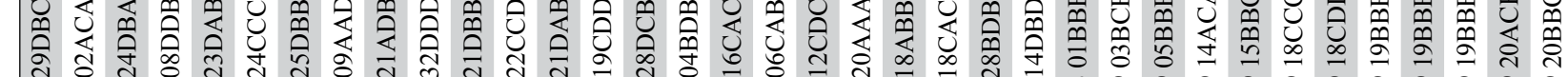
तै

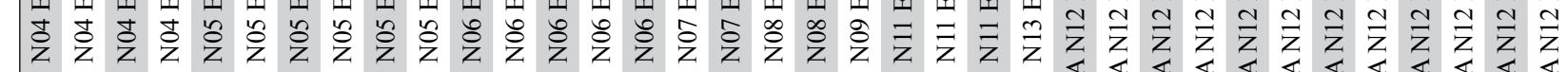

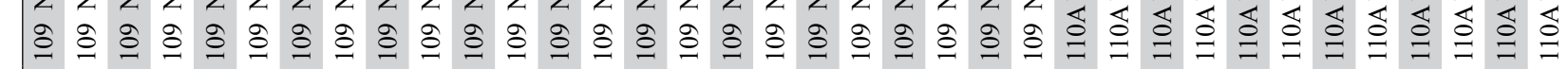

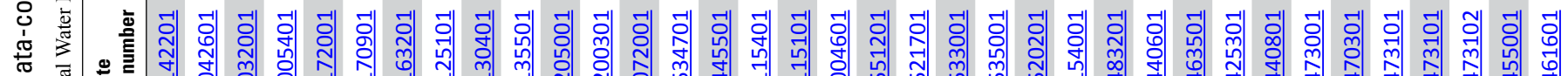

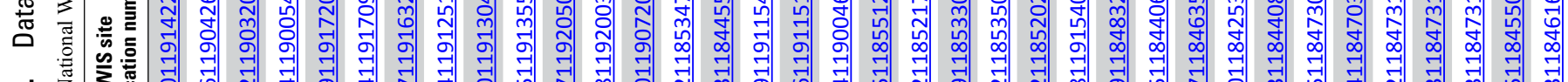




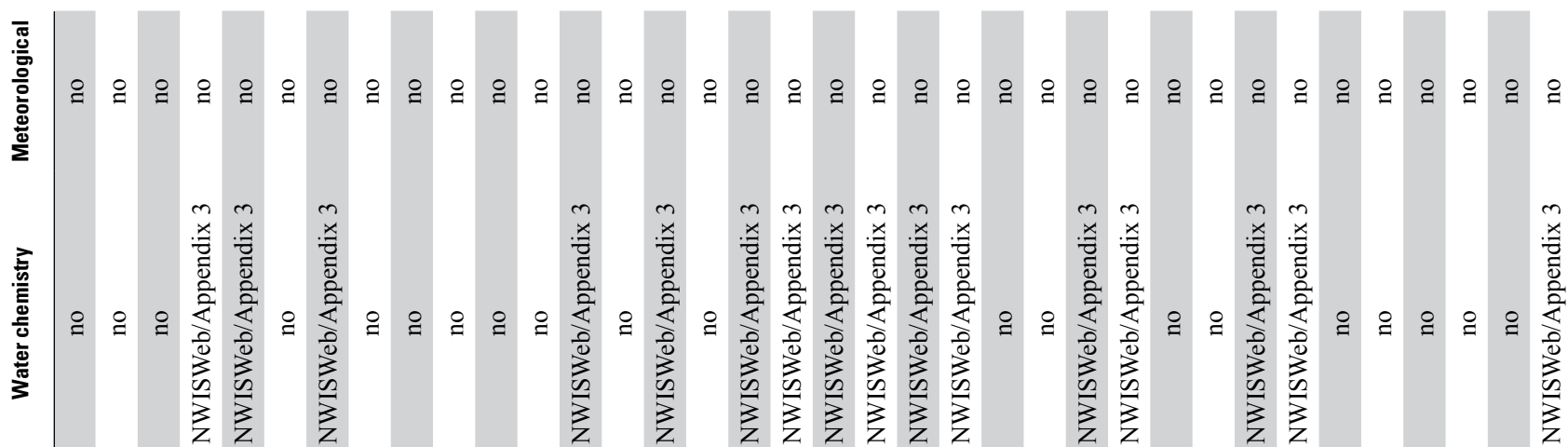

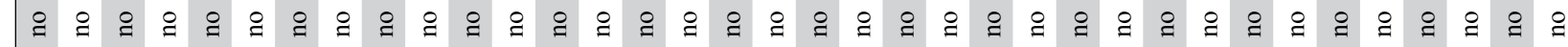
昰

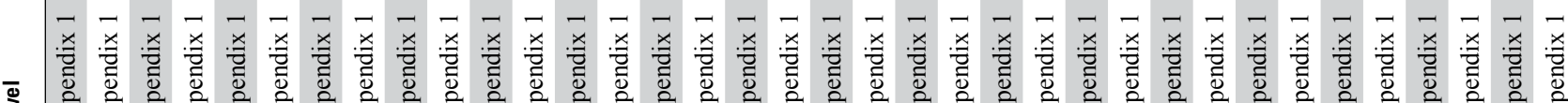

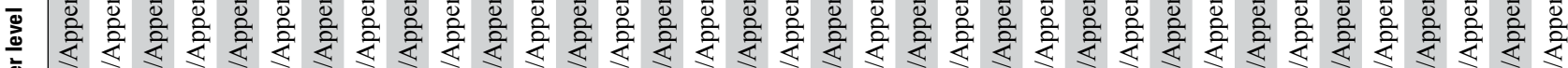

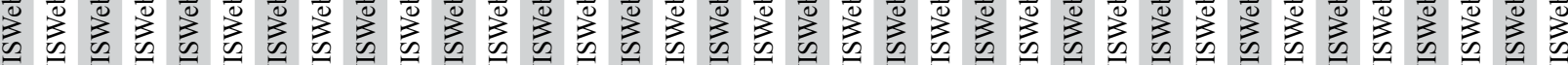

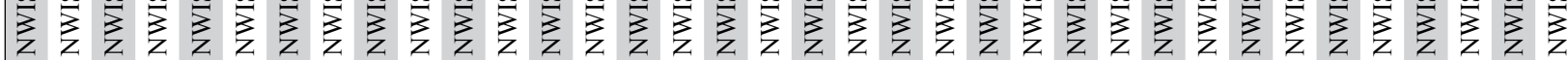

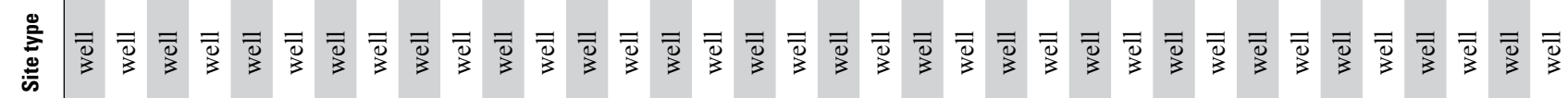
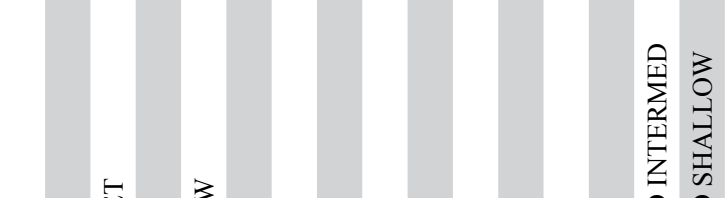

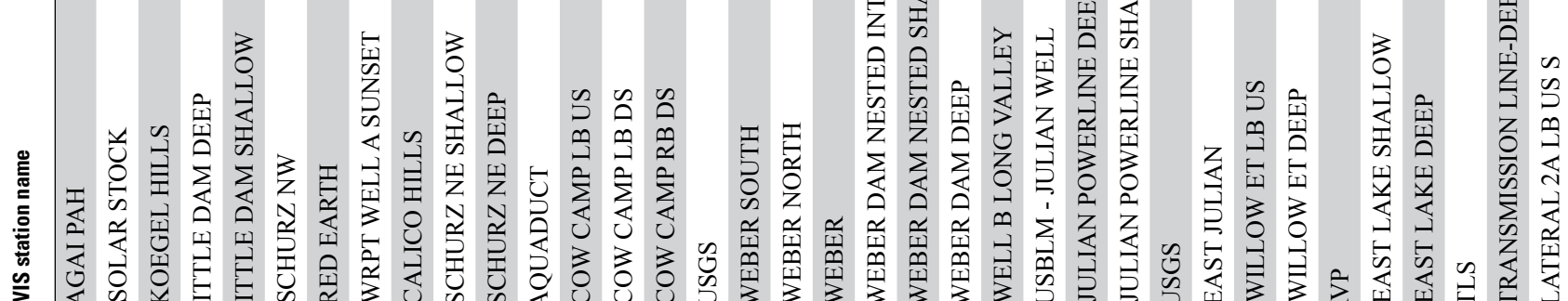

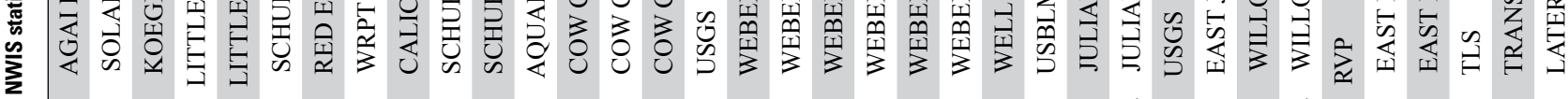

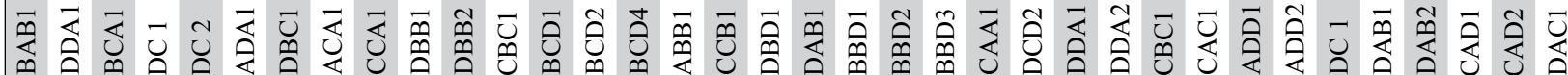

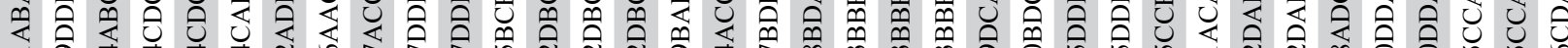

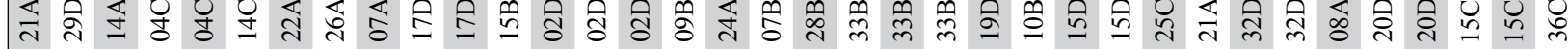
స్

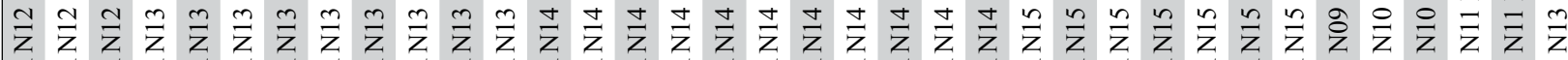

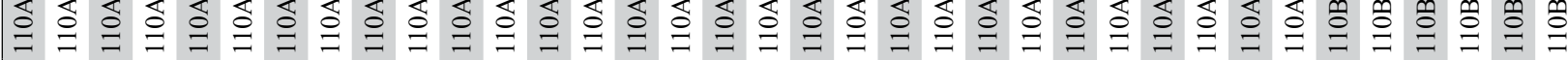




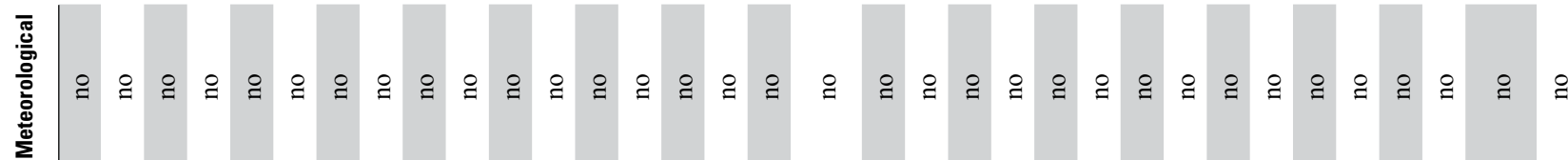

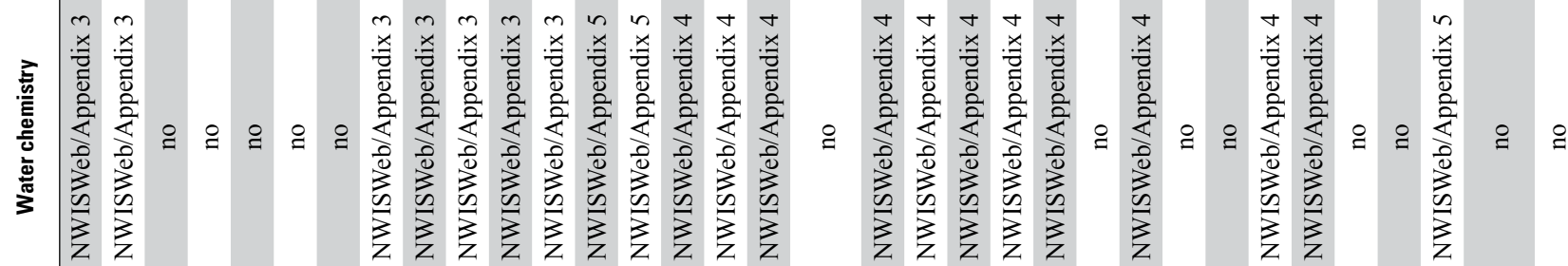

\section{善

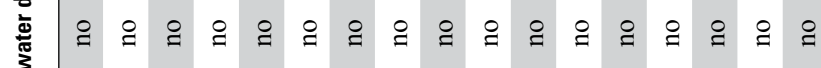

\section{苞}

兽

章

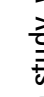$$
\text { ๓⿴囗十 }
$$

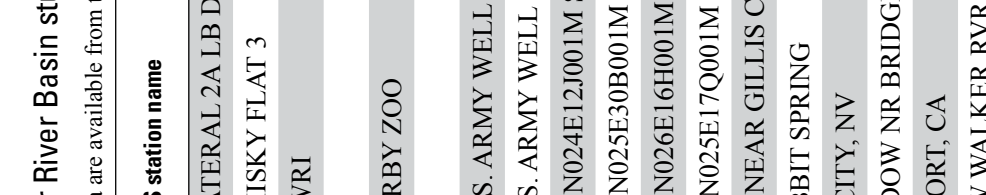

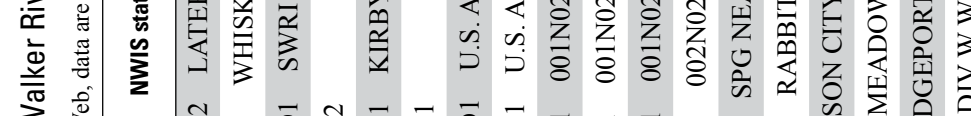

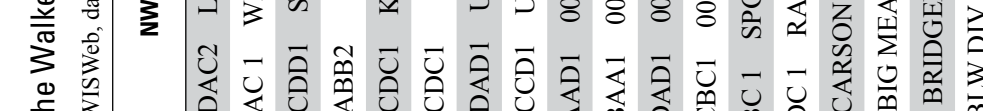

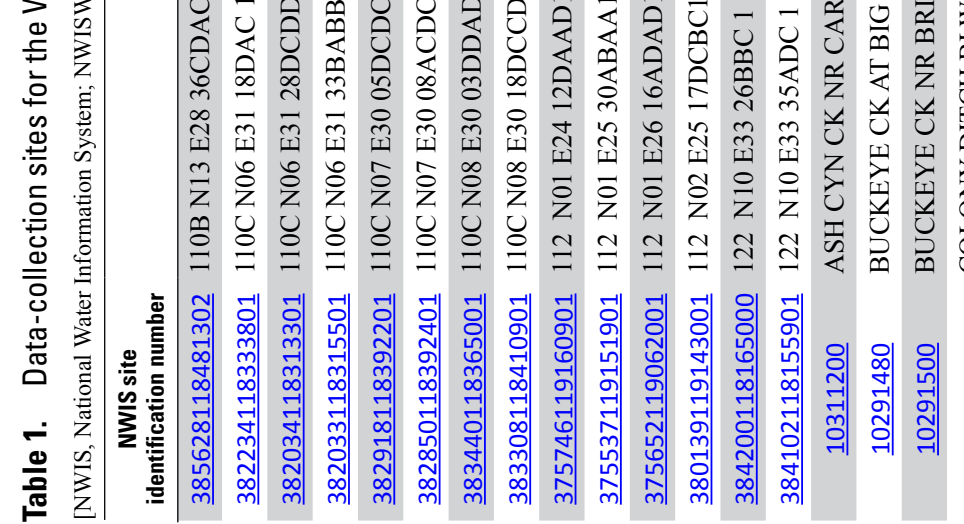

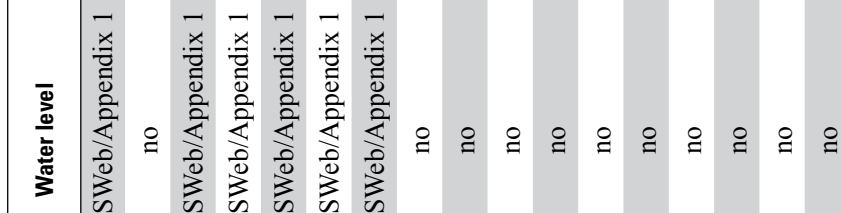
言言言充言言

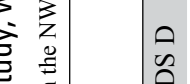

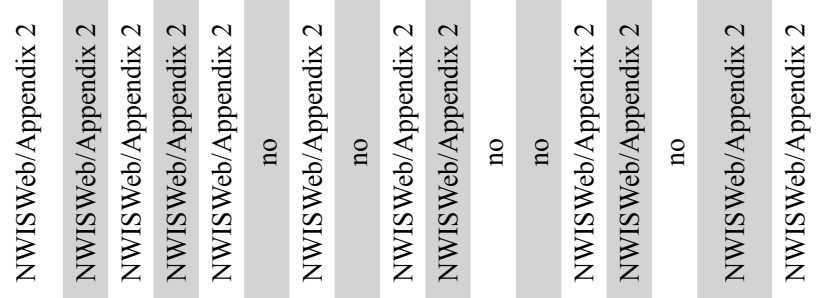

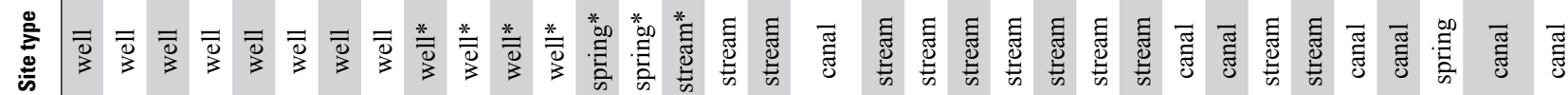




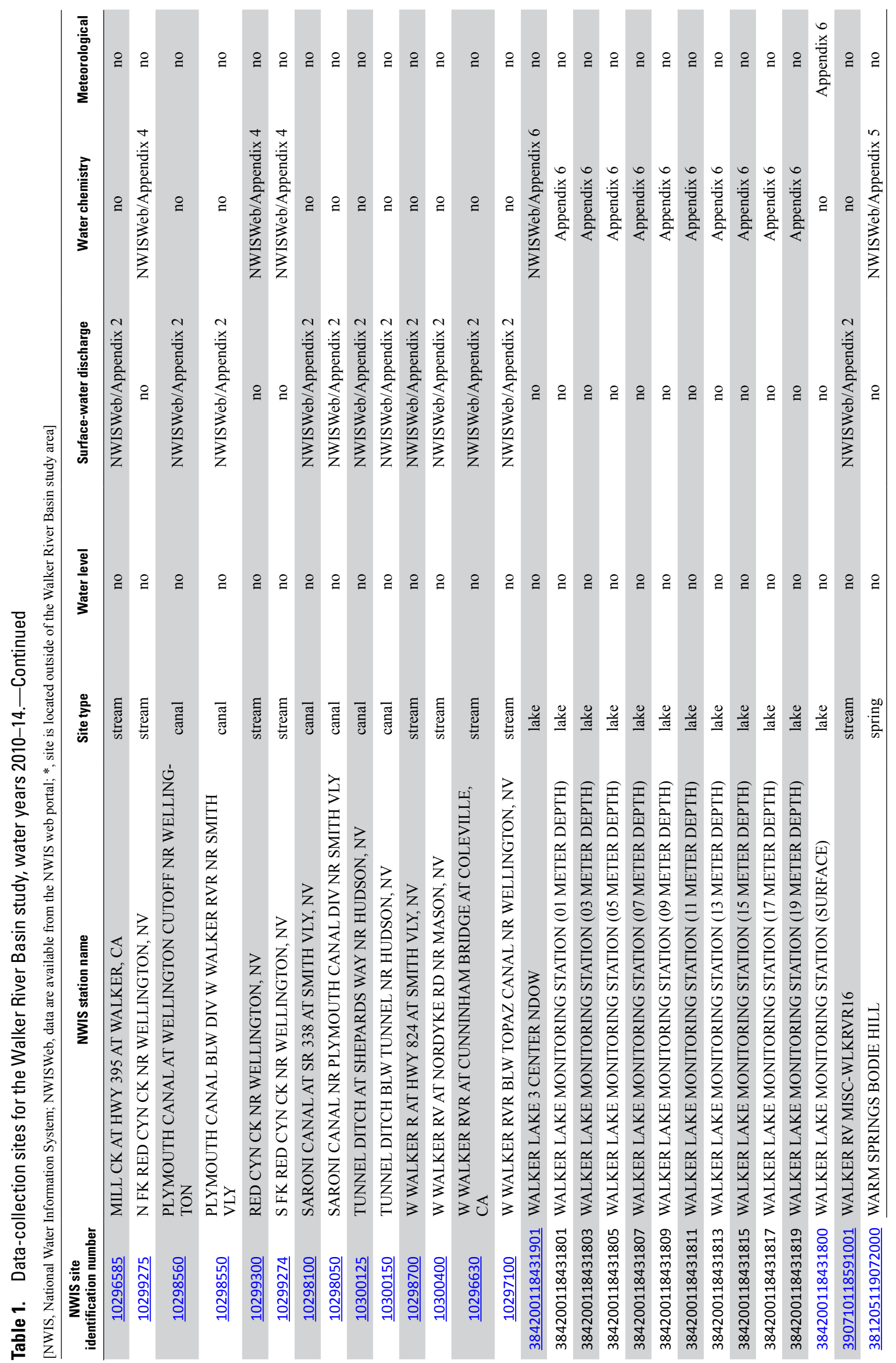




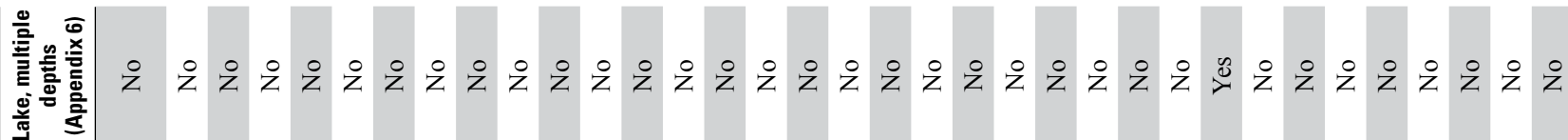

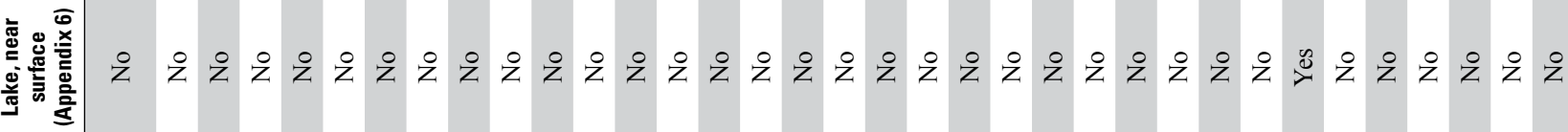

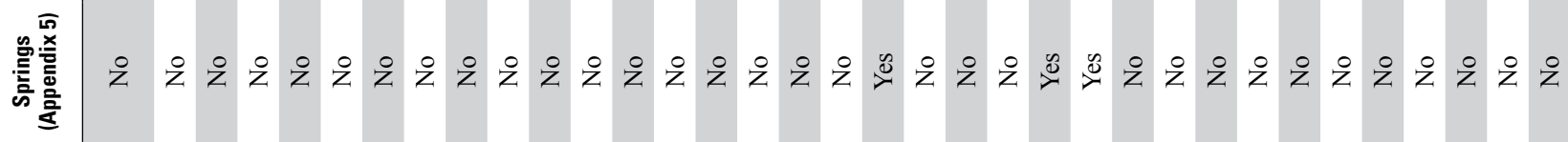

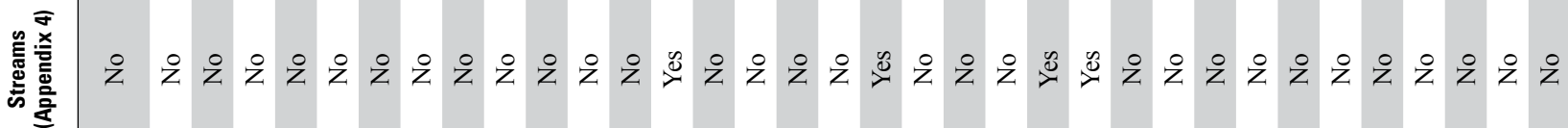

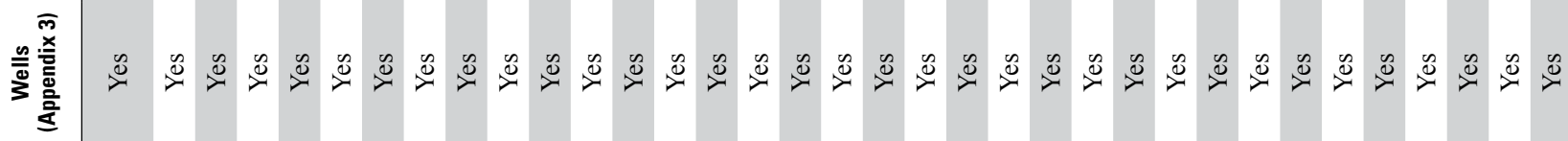

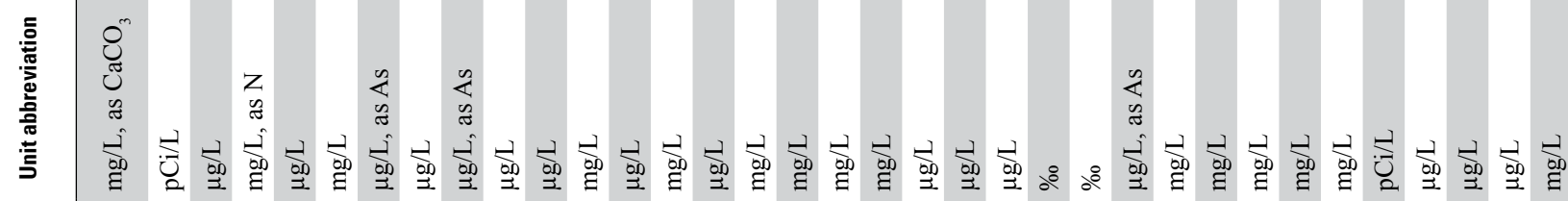

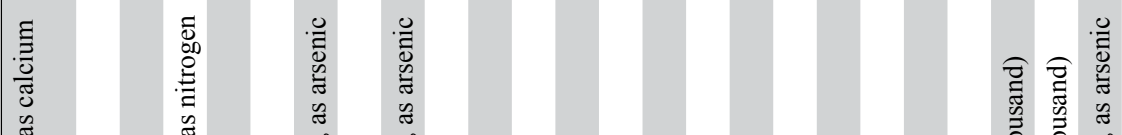

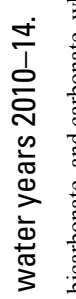

离

ᄃ

焉

$\stackrel{\bar{\phi}}{2}$

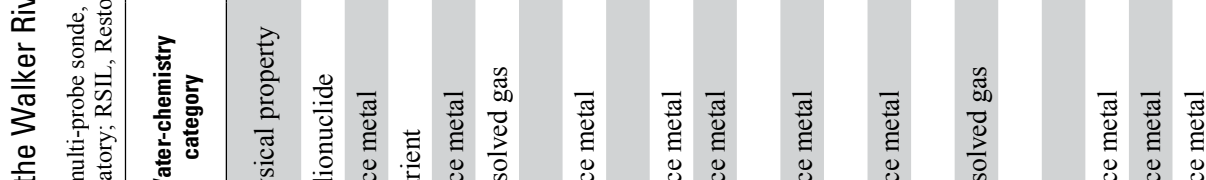

言 空

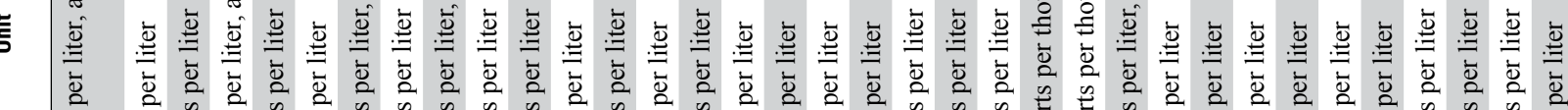

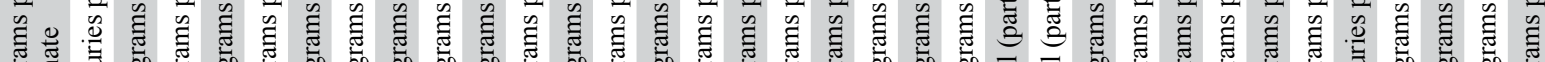
毠

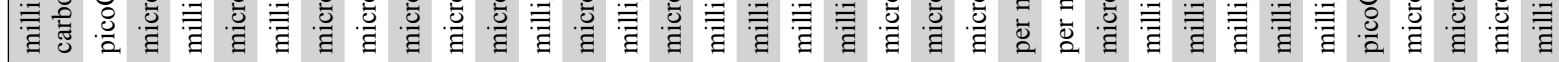

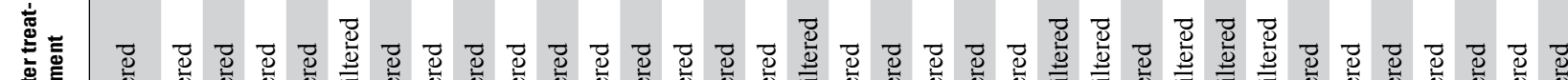

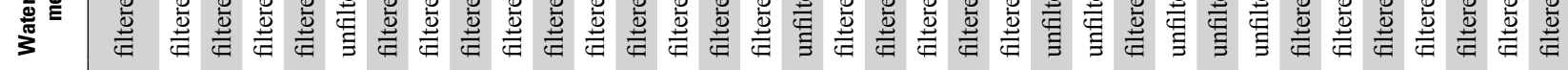

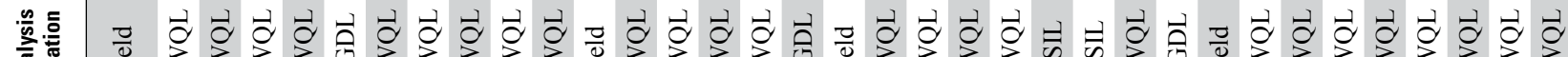

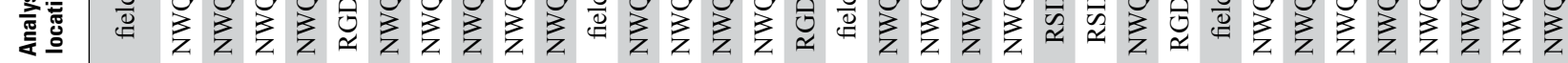

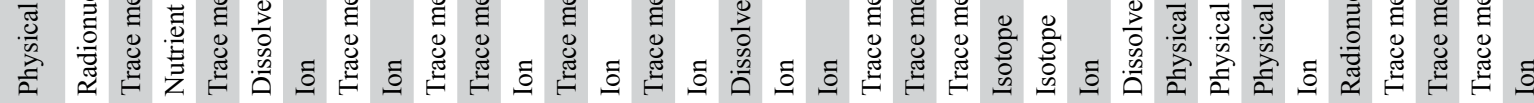

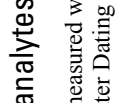

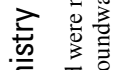

类

要要

$\sum^{\frac{2}{m}}$

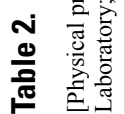
בे

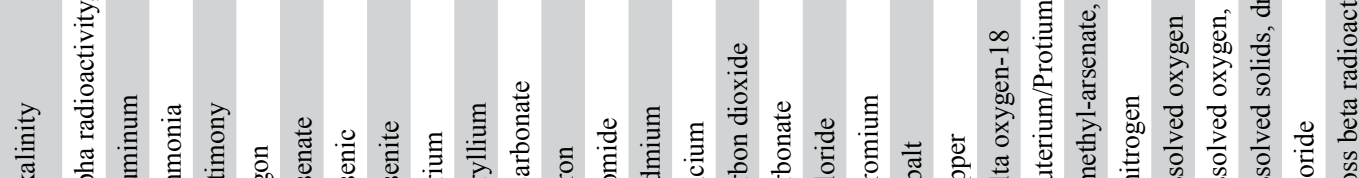

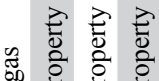
跣

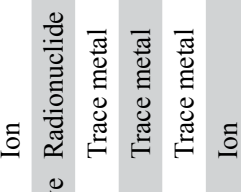

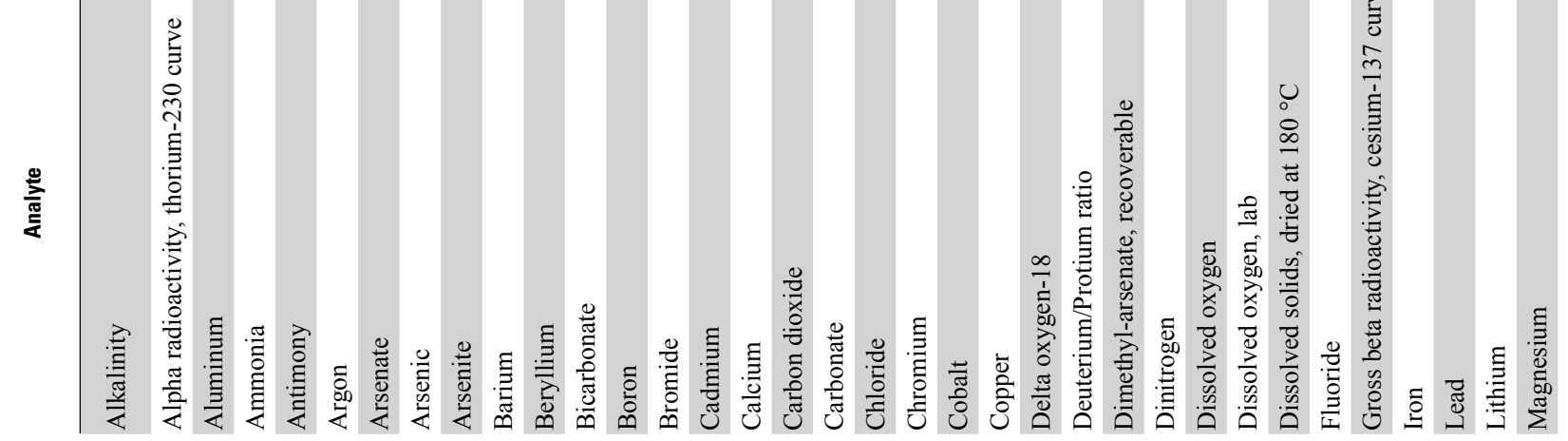




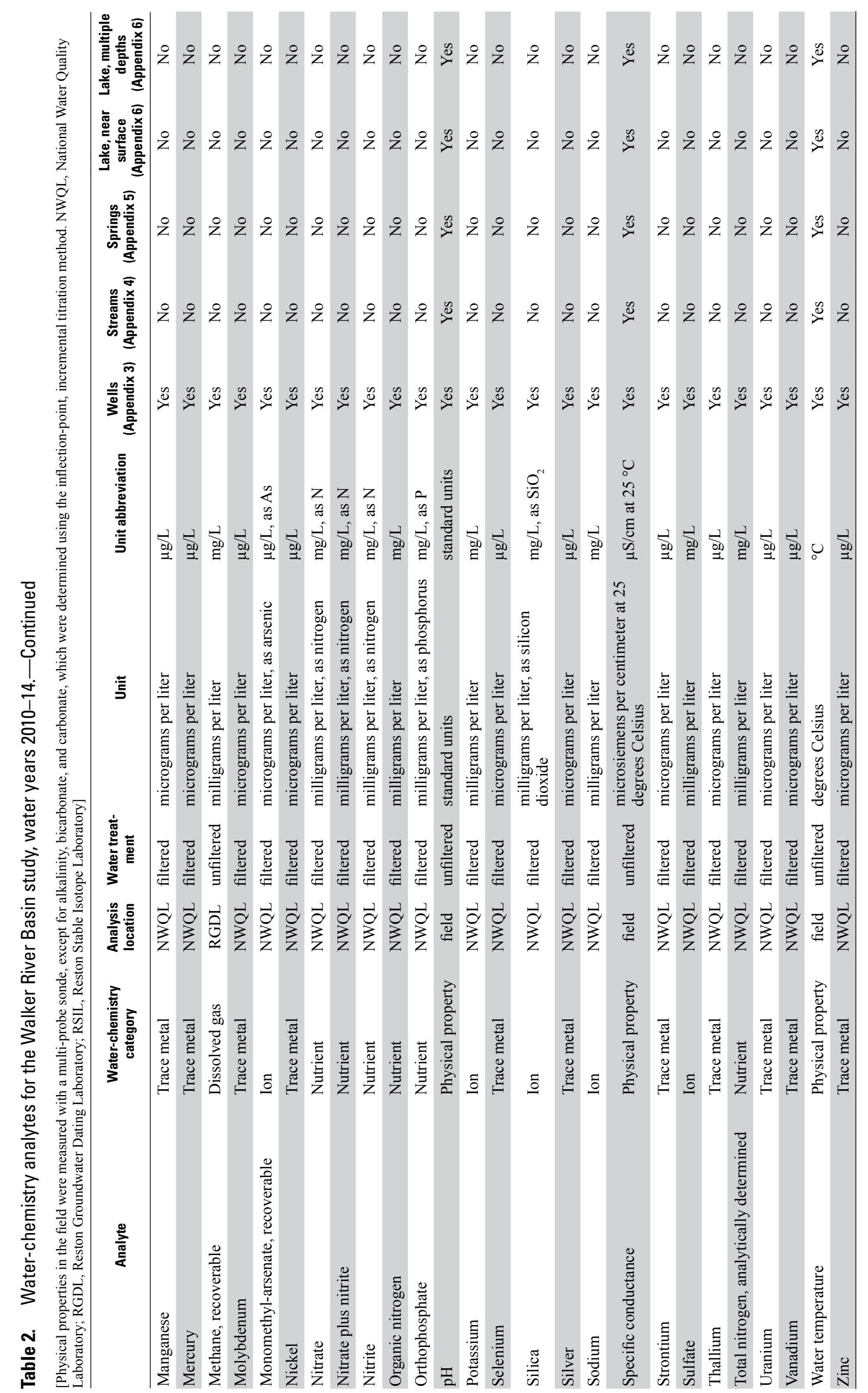




\section{Summary}

With funding from the 2002 Farm Bill and in response to declining lake levels and worsening water quality in Walker Lake, the USGS, in cooperation with the Bureau of Reclamation, began a study of the Walker River Basin in 2004. The main objective of the study was to determine how to best sustain the desert terminal lake and improve water quality. To accomplish this goal, the USGS has been collecting and analyzing hydrologic data since 2004; this report documents the data and data-collection methods for water years 2010-14.

Groundwater levels were measured in 195 wells, totaling 2,070 measurements, from October 2, 2009, to March 18, 2014. Surface-water discharge was measured in 11 streams and 13 irrigation canals, totaling 104 measurements, from January 6, 2011, to October 29, 2012. Water-chemistry data were collected at wells, streams, springs, and Walker Lake. Chemical analyses included determining physical properties; concentrations of major ions, nutrients, trace metals, dissolved gases, and radionuclides; and ratios of the stable isotopes of hydrogen and oxygen. Groundwater-chemistry samples were collected from 70 wells, totaling 107 samples, from September 15,2010 , to September 21, 2012. Stream water-chemistry samples were collected from 14 streams, totaling 359 samples, from October 21, 2010, to September 27, 2013. Spring waterchemistry samples were collected from 20 springs, totaling 20 samples, from August 18, 2011, to August 15, 2012. Walker Lake water-chemistry samples from near the lake surface were collected on November 2, 2010, and January 14, 2014. Walker Lake water-chemistry data from 1, 3, 5, 7, 9, 11, 13, 15, 17, and 19 meters below the lake surface were collected from May 3, 2011, to June 9, 2013. Meteorological data were collected on Walker Lake from March 30, 2011, to September 30, 2013. All of the data are presented in this report and accessible from NWISWeb, except multiple-depth Walker Lake water-chemistry data, which are available only in this report.

\section{References Cited}

Allander, K.K., Niswonger, R.G., and Jeton, A.E., 2014, Simulation of the lower Walker River Basin hydrologic system, west-central Nevada, using PRMS and MODFLOW models: U.S. Geological Survey Scientific Investigations Report 2014-5190, 93 p.

Allander, K.K., Smith, J.L., and Johnson, M.J., 2009, Evapotranspiration from the lower Walker River Basin, west-central Nevada, water years 2005-07: U.S. Geological Survey Scientific Investigations Report 2009-5079, 62 p.

Cunningham, W.L., and Schalk, C.W., comps., 2011, Groundwater technical procedures of the U.S. Geological Survey: U.S. Geological Survey Techniques and Methods 1-A1, 151 p., http://pubs.usgs.gov/tm/1a1/.

Dilts, T.E., Weisberg, P.J., Yang, Jian, Olson, T.J., Turner, P.L., and Condon, L.A., 2012, Using historical General Land Office survey notes to quantify the effects of irrigated agriculture on land cover change in an arid lands watershed: Annals of the Association of American Geographers, v. 102, no. 3, p. 531-548.

Lopes, T.J., and Allander, K.K., 2009a, Hydrologic setting and conceptual hydrologic model of the Walker River Basin, west-central Nevada: U.S. Geological Survey Scientific Investigations Report 2009-5155, 84 p.

Lopes, T.J., and Allander, K.K., 2009b, Water budgets of the Walker River Basin and Walker Lake, California and Nevada: U.S. Geological Survey Scientific Investigations Report 2009-5157, 44 p.

Lopes, T.J., and Smith, J.L., 2007, Bathymetry of Walker Lake, west-central Nevada: U.S. Geological Survey Scientific Investigations Report 2007-5012, 26 p.

Reheis, Marith, 1999, Extent of Pleistocene lakes in the western Great Basin: U.S. Geological Survey Miscellaneous Field Studies Map MF-2323, accessed August 19, 2004, at http://pubs.usgs.gov/mf/1999/mf-2323/.

Rowland, R.C., Westenburg, C.L., Veley, R.J., and Nylund, W.E., 2006, Physical and chemical water-quality data from automatic profiling systems, Boulder Basin, Lake Mead, Arizona and Nevada, water years 2001-04: U.S. Geological Survey Open-File Report 2006-1284, 17 p., http://pubs.water.usgs.gov/ofr2006-1284.

Turnipseed, D.P., and Sauer, V.B., 2010, Discharge measurements at gaging stations: U.S. Geological Survey Techniques and Methods book 3, chap. A8, 87 p., http://pubs.usgs.gov/tm/tm3-a8/.

U.S. Geological Survey, 2005, Science to sustain terminal lakes-The Walker River Basin study: U.S. Geological Survey Fact Sheet 2005-3124, 2 p. 
U.S. Geological Survey, 2015, National Water Information System data available on the World Wide Web (USGS

Water Data for the Nation), http://waterdata.usgs.gov/nwis/.

U.S. Geological Survey, variously dated, National field manual for the collection of water-quality data: U.S. Geological Survey Techniques of Water-Resources Investigations, book 9, chaps. A1-A9, http://pubs.water.usgs.gov/twri9A.

Veley, R.J., and Moran, M.J., 2012, Evaluating lake stratification and temporal trends by using near-continuous waterquality data from automated profiling systems for water years 2005-09, Lake Mead, Arizona and Nevada: U.S. Geological Survey Scientific Investigations Report 20125080, 25 p., http://pubs.usgs.gov/sir/2012/5080/.

Wagner, R.J., Boulger, R.W., Jr., Oblinger, C.J., and Smith, B.A., 2006, Guidelines and standard procedures for continuous water-quality monitors-Station operation, record computation, and data reporting: U.S. Geological Survey Techniques and Methods 1-D3, 51 p., plus 8 attachments, http://pubs.water.usgs.gov/tm1d3. 


\section{Appendixes}

All of the appendixes in this report are distributed in Microsoft ${ }^{\circledR}$ Excel 2010 format and are available for download at http://dx.doi.org/10.3133/ds967.

Appendix 1. Water-level measurements for the Walker River Basin study, water years 2010-14.

Appendix 2. Surface-water discharge measurements for the Walker River Basin study, water years 2011-13.

Appendix 3. Groundwater-chemistry data for the Walker River Basin study, water years 2010-12.

Appendix 4. Stream water-chemistry data for the Walker River Basin study, water years 2011-13.

Appendix 5. Spring water-chemistry data for the Walker River Basin study, water years 2010-13.

Appendix 6. Lake water-chemistry and meteorological data from sites located on Walker Lake, water years 2011-14. 




\section{ख़}

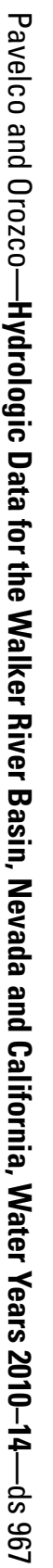

